\title{
Modelling sulphate stream concentrations in the Black Forest catchments Schluchsee and Villingen
}

\author{
A. Prechtel ${ }^{1}$, M. Armbruster ${ }^{2}$ and E. Matzner ${ }^{1}$ \\ ${ }^{1}$ Department of Soil Ecology, BITÖK, University of Bayreuth, D-95440 Bayreuth, Germany \\ ${ }^{2}$ Institute of Soil Science, Technical University of Dresden, D-01735 Tharandt, Germany \\ Email for corresponding author: Annette.Prechtel@bitoek.uni-bayreuth.de
}

\begin{abstract}
The sulphate $\left(\mathrm{SO}_{4}\right)$ released by mineralisation and desorption from soil can play an important role in determining concentrations of $\mathrm{SO}_{4}$ in streams. The MAGIC model was calibrated for two catchments in the Black Forest, Germany (Schluchsee and Villingen) and $\mathrm{SO}_{4}$ concentrations in the streams for the years 2016 and 2030 were predicted. Special emphasis was placed on the dynamics of soil sulphur (S) pools. At Schluchsee, $90 \%$ of soil $\mathrm{S}$ is stored in the organic $\mathrm{S}\left(\mathrm{S}_{\text {org }}\right)$ pool, whereas at Villingen, $54 \%$ is in the inorganic $\left(\mathrm{S}_{\text {inorg }}\right)$ pool. The Villingen stream chemistry was modelled successfully by measured Langmuir isotherm parameters (LIPs) for $\mathrm{S}_{\text {inorg. }}$. Schluchsee data could not be modelled satisfactorily using measured or freely adapted LIPs only, as the $\mathrm{S}_{\text {inorg }}$ pool would have to be more than five times larger than what was measured. With $60.5 \mathrm{mmol}_{\mathrm{c}} \mathrm{SO}_{4} \mathrm{~m}^{-2} \mathrm{yr}^{-1}$ as internal soil source by mineralisation and the measured LIPs, stream data was modelled successfully. The modelling shows that in these two catchments pre-industrial concentrations of $\mathrm{SO}_{4}$ in runoff can be reached in the next two decades if $\mathrm{S}$ deposition decreases as intended under currently agreed national and international legislation. $\mathrm{S}_{\text {org }}$ is the most likely dominant source of $\mathrm{SO}_{4}$ released at Schluchsee. Mineralization from the $\mathrm{S}_{\text {org }}$ pool must be included when modelling $\mathrm{SO}_{4}$ concentrations in the stream. As the dynamics and the controlling factors of $\mathrm{S}$ release by mineralisation are not yet clear, this process remains a source of uncertainty for predictions of $\mathrm{SO}_{4}$ concentrations in streams. Future research should concentrate on dynamics of $\mathrm{S}$ mineralisation in the field, such that mathematical descriptions of long-term S-mineralisation can be incorporated into biogeochemical models.
\end{abstract}

Keywords: sulphate release, organic $\mathrm{S}$, mineralisation, acidification, recovery, modelling, MAGIC, catchments, predictions, Germany, forest

\section{Introduction}

Since the industrial revolution, deposition of anthropogenic sulphate $\left(\mathrm{SO}_{4}\right)$ has led to $\mathrm{SO}_{4}$ accumulation in forest soils and acidification of surface waters (Reuss and Johnson, 1985). Sulphur (S) is stored in the soil as inorganic $\mathrm{SO}_{4}$ by adsorption and/or cycled through the organic $\mathrm{S}\left(\mathrm{S}_{\text {org }}\right)$ pool before being released to soil solution and stream water (Alewell, 2001). The importance of these processes depends on soil characteristics. In the upper horizons of many soils, $\mathrm{S}_{\mathrm{org}}$ is the dominant $\mathrm{S}$ fraction, and can comprise $60-90 \%$ of total S pool (David et al., 1984; Mitchell et al., 1986; Autry et al., 1990; Fitzgerald and Autry, 1992; Erkenberg et al., 1996; Prietzel et al., 2001).

$\mathrm{SO}_{4}$ release from the $\mathrm{S}_{\text {org }}$ and other soil $\mathrm{S}$ pools has become of increasing importance as the atmospheric $\mathrm{S}$ input has declined during the last two decades. A study of the response of $\mathrm{S}$ dynamics to decreasing $\mathrm{S}$ deposition in several European catchments showed a net release of $\mathrm{SO}_{4}$ in most catchments since the late 1980s and the early 1990s (Prechtel et al., 2001). As the $\mathrm{SO}_{4}$ released is accompanied in part by base cations, net $\mathrm{SO}_{4}$ loss from soil enhances soil acidification and in acid soils increases acidification of soil solution and surface water. Therefore, understanding the $\mathrm{S}$ dynamics in soil and evaluating the relevant $\mathrm{S}$ sources is crucial for predicting the reversibility of acidification.

It has been hypothesised that mineralisation of soil estersulphates (E-S) is regulated by a biological requirement for $\mathrm{S}$ whereas mineralisation of carbon-bound $\mathrm{S}(\mathrm{C}-\mathrm{S})$ is more closely associated with concomitant mineralisation of $\mathrm{C}$ and $\mathrm{N}$ as energy source for soil microbes (McGill and Cole, 1981). Norman et al. (2002) described S mineralisation as a two-step reaction during which C-S is converted slowly 
Table 1a. Site characteristics of catchments studied: area, climate, catchment discharge, bedrock, soil and vegetation.

\begin{tabular}{|c|c|c|}
\hline & Schluchsee & VILLINGEN \\
\hline Area (ha) & 11 & 46.3 \\
\hline Altitude (m a.s.l.) & $1150-1290$ & $810-945$ \\
\hline Temperature $\left(\mathrm{C}^{\circ}\right)^{*}$ & 4.4 & 6.3 \\
\hline Precipitation $\left(\mathrm{m} \mathrm{yr}^{-1}\right) * *$ & 1.87 & 1.33 \\
\hline Annual discharge $\left(\mathrm{m} \mathrm{yr}^{-1}\right)^{* *}$ & $1.40 * * *$ & $0.47 * * *$ \\
\hline $\begin{array}{l}\text { Bedrock } \\
\text { major soil types (FAO) }\end{array}$ & $\begin{array}{l}\text { Granite } \\
\text { Haplic Podzol }\end{array}$ & $\begin{array}{l}\text { triassic sandstone } \\
\text { Dystric cambisols } \\
(70 \%) \\
\text { Dystric Planosol } \\
(30 \%)\end{array}$ \\
\hline $\begin{array}{l}\text { Forest } \\
\text { Natural forest species } \\
\quad \text { composition }\end{array}$ & $\begin{array}{l}\text { Norway Spruce } \\
\text { beech, fir, } \\
\text { spruce }\end{array}$ & $\begin{array}{l}\text { Norway Spruce } \\
\text { fir, spruce, pine }\end{array}$ \\
\hline $\begin{array}{l}\text { *annual mean air temperature } \\
* * \text { annual mean } \\
* * * \text { hydrological years }\end{array}$ & & \\
\hline
\end{tabular}

to E-S followed by fast hydrolysis of E-S. The factors controlling mineralisation rates in the field, however, are are poorly known.

Alewell (2001) and Gbondo-Tugbawa et al. (2002) among others suggested that $\mathrm{SO}_{4}$ released from mineralisation can play an important role in concentrations of $\mathrm{SO}_{4}$ in streams. The discrepancy between measured and modelled $\mathrm{SO}_{4}$ concentrations was reduced considerably when biotic processes such as plant uptake and mineralisation were included in the model (PnET-BGC) (Gbondo-Tugbawa et al., 2002). They suggested that under conditions of decreasing $\mathrm{S}$ deposition, mineralisation in excess of immobilization and plant uptake becomes more important in controlling $\mathrm{SO}_{4}$ losses than $\mathrm{SO}_{4}$ desorption and that models which only describe abiotic processes will not be suitable for predicting long-term recovery of stream water from acidification. Most biogeochemical models for soil and water acidification consider inorganic $\mathrm{SO}_{4}$ adsorption and desorption only. Thus, specific results from forecasts are highly dependent on the assumptions made concerning the $\mathrm{S}$ sources to and within the catchment (Gbondo-Tugbawa et al., 2002).

$\mathrm{S}$ pools and $\mathrm{SO}_{4}$ dynamics of the Black Forest, Germany, catchments Schluchsee and Villingen (Table 1a) have been analysed by Feger et al. (1990), Feger (1993a,b), Armbruster (1998) and Prietzel (1998a). These detailed data, the proximity of the catchments to each other (same deposition history), and their differences in soil $\mathrm{S}$ pools and $\mathrm{S}$ release make these catchments well-suited for this attempt to model the past and future concentrations of $\mathrm{SO}_{4}$ in streamwater. At Schluchsee, $90 \%$ of total $\mathrm{S}$ is found in the organic fraction $\left(\mathrm{S}_{\text {org }}\right)$, whereas at Villingen only $54 \%$ is in this pool (Table 1b). The absolute amounts of $\mathrm{S}_{\text {org }}$, however, are similar in both catchments. While at Schluchsee the $\mathrm{SO}_{4}$ net loss (input minus output) was $50 \mathrm{mmol}_{\mathrm{c}} \mathrm{SO}_{4} \mathrm{~m}^{-2} \mathrm{yr}^{-1}$ (mean 1988-1996), the $\mathrm{SO}_{4}$ budget at Villingen was almost balanced (1988-1995). Feger et al. (1990) suggested that mineralisation of the $\mathrm{S}_{\text {org }}$ pool is the most likely $\mathrm{SO}_{4}$ source at Schluchsee. Furthermore, a comparison of soil $\mathrm{S}$ pools (forest floor and $0-80 \mathrm{~cm}$ ) with the cumulative $\mathrm{SO}_{4}$ net

Table 1b. Pools of total $\mathrm{S}\left(\mathrm{S}_{\text {tot }}\right)$, organic $\mathrm{S}\left(\mathrm{S}_{\text {org }}\right)$, inorganic $\mathrm{S}\left(\mathrm{S}_{\text {inorg }}\right)$, carbon-bound $\mathrm{S}(\mathrm{C}-\mathrm{S})$ and estersulphate-S (E-S) in the main soil types (O-horizon and 0-100 cm) of the studied catchments Schluchsee and Villingen (after Prietzel, 1998a) (pools were determined in samples from 1986). Measured values and percentages of total S.

\begin{tabular}{|c|c|c|c|c|c|c|c|c|c|c|c|}
\hline $\mathrm{mmol} \mathrm{S} \mathrm{m} \mathrm{m}^{-2}$ & Podzol & & & & & & & & & & \\
\hline SCHLuChSEE & Depth [cm] & $S_{t o t}$ & & $S_{\text {org }}$ & & $S_{\text {inorg }}$ & & $C-S$ & & $E-S$ & \\
\hline $\mathrm{O}$ & $5-0$ & 372 & $12 \%$ & 363 & $12 \%$ & 9 & $0 \%$ & 281 & $9 \%$ & 84 & $3 \%$ \\
\hline A & $0-30$ & 928 & $30 \%$ & 872 & $29 \%$ & 56 & $2 \%$ & 506 & $17 \%$ & 366 & $12 \%$ \\
\hline B & $30-80$ & 1534 & $50 \%$ & 1338 & $44 \%$ & 197 & $6 \%$ & 819 & $27 \%$ & 519 & $17 \%$ \\
\hline \multirow[t]{2}{*}{$\mathrm{C}$} & $80-100$ & 225 & $8 \%$ & 175 & $5 \%$ & 50 & $2 \%$ & 19 & $1 \%$ & 156 & $5 \%$ \\
\hline & Sum & 3059 & $100 \%$ & 2744 & $90 \%$ & 316 & $10 \%$ & 1625 & $53 \%$ & 1125 & $37 \%$ \\
\hline $\mathrm{mmol} \mathrm{S} \mathrm{m}^{-2}$ & Cambisol & & & & & & & & & & \\
\hline VILLINGEN & Depth [cm] & $S_{t o t}$ & & $S_{\text {org }}$ & & $S_{\text {inorg }}$ & & $C-S$ & & $E-S$ & \\
\hline $\mathrm{O}$ & $6-0$ & 422 & $9 \%$ & 409 & $9 \%$ & 13 & $0 \%$ & 331 & $7 \%$ & 75 & $2 \%$ \\
\hline $\mathrm{A}, \mathrm{AB}$ & $0-20$ & 975 & $20 \%$ & 856 & $18 \%$ & 119 & $3 \%$ & 569 & $12 \%$ & 288 & $6 \%$ \\
\hline $\mathrm{B}, \mathrm{BC}$ & $20-70$ & 2447 & $51 \%$ & 859 & $18 \%$ & 1584 & $33 \%$ & 369 & $8 \%$ & 491 & $10 \%$ \\
\hline \multirow[t]{2}{*}{$\mathrm{C}$} & $70-100$ & 922 & $19 \%$ & 438 & $9 \%$ & 484 & $10 \%$ & 166 & $3 \%$ & 272 & $6 \%$ \\
\hline & Sum & 4766 & $100 \%$ & 2563 & $54 \%$ & 2203 & $46 \%$ & 1434 & $30 \%$ & 1125 & $24 \%$ \\
\hline
\end{tabular}


release (1988-1995) showed that the release at Schluchsee cannot be explained by losses from the inorganic $\mathrm{SO}_{4}$ pool (Alewell, 2001). The catchment received $253 \mathrm{mmol}_{\mathrm{c}} \mathrm{S} \mathrm{m}^{-2}$ $\mathrm{yr}^{-1}$ and released $550 \mathrm{mmol}_{\mathrm{c}} \mathrm{S} \mathrm{m}^{-2} \mathrm{yr}^{-1}$ with seepage water. With an inorganic $\mathrm{S}$ pool of $263 \mathrm{mmol}_{\mathrm{c}} \mathrm{S} \mathrm{m}^{-2}$ and a $\mathrm{S}_{\text {org }}$ pool of $2572 \mathrm{mmol}_{\mathrm{c}} \mathrm{S} \mathrm{m}^{-2}$, the net release of $297 \mathrm{mmol}_{\mathrm{c}} \mathrm{S} \mathrm{m}^{-2}$ $\mathrm{yr}^{-1}$ most likely originates from the $\mathrm{S}_{\text {org }}$ pool.

The aims of this study were to (i) apply the model MAGIC to the two catchments Schluchsee and Villingen and predict concentrations of $\mathrm{SO}_{4}$ in the streams in the years 2016 and 2030 and (ii) to evaluate the role of soil S pools for modelling $\mathrm{SO}_{4}$ stream concentrations. The year 2016 was chosen as it is the year by which 'good surface water status' is to be achieved in the implementation of the Water Framework Directive (European Commission, 2000), and 2030 was chosen as a further forecast target year.

\section{Methods}

\section{DESCRIPTION OF CATCHMENTS}

The catchments, Schluchsee $\left(47^{\circ} 49^{\prime} \mathrm{N}, 8^{\circ} 06^{\prime} \mathrm{E}\right)$ and Villingen $\left(48^{\circ} 03^{\prime} \mathrm{N}, 8^{\circ} 22^{\prime} \mathrm{E}\right)$ are located in the higher altitudes of the Black Forest (Table 1a). Both catchments are completely forested and have not been affected by agricultural activities, fertilization or road salts. Research in the catchments started in 1988 (Feger, 1993a) and deposition and stream chemistry data has been collected from 1988 until 1995 and 1996 at Villingen and Schluchsee, respectively. A detailed description of the catchments is given in Feger et al. (1990), Feger (1993a), and Mayer et al. (1995).

The Schluchsee catchment is covered by well-drained Podzols of 60-100 cm depth. Prevailing soil types at Villingen are dystric Cambisols (70\% of catchment area) and dystric Planosols (30\% of catchment area) of about $70 \mathrm{~cm}$ depth (Feger, 1993a). S pools in the catchments differ greatly (Table 1b).
Elemental ratios in the organic matter of the soils also differ between the catchments (Table 1c). According to Prietzel (1998a), mineralisation of humus and adsorption of E-S explain the higher $\mathrm{C}_{\text {org }} / \mathrm{S}_{\text {org }}$-ratios in the Schluchsee Ahe- and Bsh-horizon, respectively, than in the organic layers. Due to this, four times more $\mathrm{S}_{\text {org }}$ is adsorbed to the soil than $\mathrm{SO}_{4}-\mathrm{S}$. In contrast at Villingen, all of the adsorbed $\mathrm{S}$ in the deeper mineral soil is $\mathrm{SO}_{4}-\mathrm{S}$. The small $\mathrm{C}_{\text {org }} / \mathrm{S}_{\text {org }}-$ ratio in the Bv2 might be a result of the very low $\mathrm{C}_{\text {org }}$ - and $\mathrm{S}_{\text {org }}$-contents. Removed S-rich organic matter from the organic layers is also stored in the upper mineral soil at Villingen.

Atmospheric $\mathrm{SO}_{4}$ input of $56-59 \mathrm{mmol}_{\mathrm{c}} \mathrm{SO}_{4} \mathrm{~m}^{-2} \mathrm{yr}^{-1}$ (mean 1988-1995/1996) to the catchments Schluchsee and Villingen is low to moderate as compared with other German and central European forested catchments (Prechtel et al., 2001). The Black Forest catchments are relatively remote; long-range transport of air-pollutants is more important than emissions from local sources and the inputs are very similar to the levels measured in southern Scandinavia (Feger et al., 1990).

Average $\mathrm{SO}_{4}$ concentrations in streamwater (1988-1995/ 1996) were 75 (Schluchsee) and 115 (Villingen) $\mu \mathrm{mol}_{\mathrm{c}} \mathrm{SO}_{4}$ $1^{-1}$; these levels are similar to those of the Norwegian streams Birkenes, Langtjern and Storgama (same time period) and are much lower than in streams of other low mountain ranges in Germany, e.g.: Lehstenbach (341 $\left.\mu \mathrm{mol}_{\mathrm{c}} \mathrm{SO}_{4} \mathrm{l}^{-1}\right)$ and Lange Bramke $\left(252 \mu \mathrm{mol}_{\mathrm{c}} \mathrm{SO}_{4} \mathrm{l}^{-1}\right)$ (same time period) (Prechtel et al., 2001).

\section{Model set-up}

\section{MODEL DESCRIPTION}

The MAGIC (version 7) model is a simplified processoriented model for forecasting effects of acidic deposition on water quality and is described in detail by Cosby et al. (1986, 2001). Many applications of MAGIC aim to forecast

Table 1c. C/N- and $\mathrm{C}_{\text {org }} / \mathrm{S}_{\text {org }}$-ratios in the main soil types (O-horizon and 0-45/80 cm) of the studied catchments Schluchsee and Villingen (after Prietzel, 1998a) (pools were determined in samples from 1986).

\begin{tabular}{llllllll}
\hline $\begin{array}{l}\text { Schluchse } \\
\text { Horizon }\end{array}$ & $\begin{array}{l}\text { Podzol } \\
\text { Depth }[\mathrm{cm}]\end{array}$ & $\mathrm{C} / \mathrm{N}$ & $C_{\text {org }} / S_{\text {org }}$ & $\begin{array}{l}\text { Villingen } \\
\text { horizon }\end{array}$ & $\begin{array}{l}\text { Cambisol } \\
\text { depth }[\mathrm{cm}]\end{array}$ & $C / N$ & $C_{\text {org }} / S_{\text {org }}$ \\
\hline Of & & 30 & 277 & Of & & 37 & 286 \\
Oh & & 27 & 190 & Oh & & 40 & 247 \\
Ahe & $0-30$ & 20 & 159 & Ah & $0-12$ & 17 & 163 \\
Bsh & $30-40$ & 19 & 167 & Ah-Bv & $12-20$ & 13 & 162 \\
Bs & $40-60$ & 27 & 242 & Bv1 & $20-28$ & 11 & 175 \\
Bvs & $60-80$ & 23 & 247 & Bv2 & $28-45$ & 9 & 104 \\
\hline
\end{tabular}


timescales of reversibility of acidification of lakes and streams. As a lumped-parameter model it is assumed that a set of 'average' physical and chemical parameters can be found to describe effectively the response of a whole catchment (Cosby et al., 1986). Major soil processes in MAGIC are cation exchange, weathering, plant uptake and $\mathrm{SO}_{4}$ sorption which is described by a Langmuir isotherm. The Langmuir isotherm parameters (LIPs) $\mathrm{E}_{\max }$ (maximum $\mathrm{SO}_{4}$ adsorption capacity, in $\mathrm{mmol}_{\mathrm{c}} \mathrm{kg}^{-1}$ ) and $\mathrm{C}$ (half saturation constant, in $\mathrm{mmol}_{\mathrm{c}} \mathrm{m}^{-3}$ ) are MAGIC input parameters which have to be set for calibrating the model to the observed stream $\mathrm{SO}_{4}$ data. Further, the model requires a number of fixed parameters to describe the stream and soil physically and chemically.

\section{ROUTING PARAMETERS - SOIL BOXES}

The model represents the catchment soil as a homogeneous unit that can be described in 'soil boxes' of which one (Schluchsee: Podzol) or two (Villingen: Cambisol and Planosol) can be defined. Soil boxes can be arranged horizontally (as soil layers) or vertically (as soil types); for the latter version the percentage of covered area or rather of flow fractions through the soils must be set (used at Villingen; see Table 1). Parameters for these soil boxes include bulk density, CEC (cation exchange capacity), dissolved organic carbon (DOC) and the LIPs and were weighted over soil depth (Table 2a). The LIPs chosen for the different calibrations are shown later (see Calibration).

\section{DEPOSITION AND STREAM DATA}

The last year of the data set was used as reference year for calibration, which was 1995 and 1996 at Villingen and

Table 2a. MAGIC input: Soil characteristics of the catchments (soil depth, bulk density, cation exchange capacity (CEC), base saturation and DOC).

\begin{tabular}{|c|c|c|c|}
\hline & SCHLUCHSEE* & $\begin{array}{c}\text { VILLINGEN } \\
\text { soil box } \\
1^{\#}\end{array}$ & $\begin{array}{l}* \\
\text { soil box } \\
2^{\# \#}\end{array}$ \\
\hline Soil depth (m) & 0.8 & 0.7 & 0.7 \\
\hline Bulk density $\left(\mathrm{kg} \mathrm{m}^{-3}\right)$ & 1083 & 1335 & 1661 \\
\hline CEC (meq kg-1) & 55.8 & 60.2 & 23.3 \\
\hline Base saturation ( $\%$ of CEC) & 3 & 3.3 & 4.6 \\
\hline $\mathrm{DOC}\left(\mathrm{mmol} \mathrm{m}^{-3}\right)$ & 55.3 & 32.8 & 32.8 \\
\hline \multicolumn{4}{|c|}{$\begin{array}{l}\text { *profile weighted over } 80 \mathrm{~cm} \text { (A- and B-horizons) } \\
\text { **profile weighted over } 70 \mathrm{~cm} \text { (A- and B-horizons) }\end{array}$} \\
\hline
\end{tabular}

Table $2 b$. MAGIC input: Deposition chemistry in reference year.

\begin{tabular}{lcc}
\hline $\begin{array}{l}\text { Deposition } \\
\text { Concentration }\end{array}$ & $\begin{array}{l}\text { SchluchseE* } \\
\mu m o l_{c} l^{-1}\end{array}$ & $\begin{array}{l}\text { VILLINGEN** } \\
\mu m o l_{c} l^{-1}\end{array}$ \\
\hline $\mathrm{Ca}$ & 9.8 & 10.8 \\
$\mathrm{Mg}$ & 2.8 & 3.5 \\
$\mathrm{Na}$ & 10.2 & 8.8 \\
$\mathrm{~K}$ & 4.4 & 5.4 \\
$\mathrm{NH}_{4}$ & 15.2 & 11.5 \\
$\mathrm{SO}_{4}$ & 29.8 & 22.5 \\
$\mathrm{Cl}^{2}$ & 16.8 & 14.6 \\
$\mathrm{NO}_{3}$ & 23.3 & 15.5 \\
$* 1996$ & & \\
$* * 1995$ & & \\
\hline
\end{tabular}

Table 2c. MAGIC target values: Stream chemistry in reference year.

\begin{tabular}{|c|c|c|}
\hline $\begin{array}{l}\text { Stream } \\
\text { Concentration }\end{array}$ & $\begin{array}{l}\text { SCHLUCHSEE* } \\
\mu^{*} \mathrm{~mol}_{c} l^{-1}\end{array}$ & $\begin{array}{l}\text { VILLINGEN** } \\
\text { mol }_{c} l^{-1}\end{array}$ \\
\hline $\mathrm{Ca}$ & 51.5 & 39.8 \\
\hline $\mathrm{Mg}$ & 12.7 & 26.6 \\
\hline $\mathrm{Na}$ & 78.2 & 35.8 \\
\hline K & 15.1 & 12.0 \\
\hline $\mathrm{NH}_{4}$ & 0.2 & 0.2 \\
\hline $\mathrm{NO}_{3}$ & 37.6 & 4.4 \\
\hline $\mathrm{Cl}$ & 17.9 & 29.0 \\
\hline $\mathrm{SO}_{4}$ & 67.0 & 96.5 \\
\hline $\mathrm{ANC}^{\mathrm{x}}$ & 35.1 & -15.5 \\
\hline $\mathrm{BC}^{\mathrm{xx}}$ & 157.4 & 114.2 \\
\hline $\mathrm{Ph}$ & 5.6 & 4.5 \\
\hline \multicolumn{3}{|l|}{ * 1996} \\
\hline \multicolumn{3}{|l|}{$* * 1995$} \\
\hline \multicolumn{3}{|c|}{${ }^{\mathrm{x}}$ Acid Neutralising Capacity } \\
\hline${ }^{\mathrm{xx}}$ Sum of base ca & & \\
\hline
\end{tabular}

Schluchsee, respectively (Armbruster, 1998). Data for deposition and stream chemistry for these years are given in Tables $2 \mathrm{~b}$ and 2c. Deposition of $\mathrm{Na}^{+}, \mathrm{NO}_{3}^{-}, \mathrm{NH}_{4}{ }^{+}$and $\mathrm{SO}_{4}{ }^{2-}$ was set equal to measured throughfall in the catchments. $\mathrm{Ca}^{2+}-, \mathrm{Mg}^{2+}-, \mathrm{K}^{+}$- and $\mathrm{Cl}-$-bulk deposition was multiplied by the $\mathrm{Na}_{\text {throughfall }}$ to $\mathrm{Na}_{\text {bulk deposition }}$ ratio to calculate total deposition (Prechtel et al., 2001).

For the hindcast, $\mathrm{SO}_{4}$ deposition was estimated from $\mathrm{S}$ emissions data in Europe (Mylona, 1996) combined with currently calculated data for the period since 1960 (Schöpp et al., 2003). As both catchments are situated in the same EMEP grid square the hindcast deposition scenario was the same for Schluchsee and Villingen. 


\section{SINKS AND SOURCES}

In MAGIC the S sink 'net uptake' is defined as uptake necessary for tree biomass increment. Feger (1993b) reported annual element uptake rates for increment of 45year and 100-year old spruce trees at Schluchsee (14 mmol $\mathrm{SO}_{4} \mathrm{~m}^{-2} \mathrm{yr}^{-1}$ ) and Villingen (6 $\left.\mathrm{mmol}_{\mathrm{c}} \mathrm{SO}_{4} \mathrm{~m}^{-2} \mathrm{yr}^{-1}\right)$, respectively (Feger, 1993b). Assuming that during tree growth element uptake increases and reaches a maximum sometime after the juvenile phase a 'sink sequence' for base cations and also $\mathrm{S}$ was constructed to reflect forest history in the catchments: At Schluchsee the natural forest was clearcut in 1750 and a pure spruce forest was planted. After another clearcut in 1943, 100\% spruce was planted again. At Villingen, the old coniferous forest (see Table 1a) was clearcut in 1887 and replanted with $100 \%$ spruce.

\section{CALIBRATION}

With the parameters and assumptions described above, MAGIC was calibrated to target year values of stream and soil chemistry and further by comparing the long-term trends of element concentrations with the measured data set. Strong acid anion concentrations $\left(\mathrm{NO}_{3}{ }^{-}, \mathrm{Cl}^{-}\right.$and $\left.\mathrm{SO}_{4}{ }^{2-}\right)$ were calibrated first. Base cation concentrations were then calibrated by adjusting base cation exchange selectivity coefficients and base cation weathering in an interactive procedure until the model simulations matched the observed data. Finally, $\mathrm{pH}$ and concentrations of organic anions in the stream were calibrated by adjusting parameters controlling weak acid-base chemistry (Sullivan and Cosby, 1998).

For calibrating $\mathrm{SO}_{4}$ in the stream, LIPs have to be set in the parameter file. For Schluchsee Podzol, Villingen Cambisol and Villingen Planosol $\mathrm{E}_{\max }$ and $\mathrm{C}$ have been determined in the A- and B-horizons by Kurth et al. (1989) in a batch extraction. For the first calibration, these LIPs were used (Table 3). At Schluchsee different calibrations were run: For calibration 2, $\mathrm{E}_{\max }$ was calculated from the measured soil S pool (Prietzel, 1998a) (Table 3). In calibration 3, LIPs were the result of an interactive procedure: the best approach to the measured $\mathrm{SO}_{4}$ stream concentration was modelled by adjusting freely chosen LIPS (Table 3). After that, calibrations $4 \mathrm{a}$ and $4 \mathrm{~b}$ were run with an additional $\mathrm{S}$ source term that is attributed to net mineralisation of the soil $\mathrm{S}_{\text {org }}$ pool (Table 3).

\section{FORECAST}

The so-called 'current legislation scenario' for the decrease in $\mathrm{S}$ deposition was used. This scenario assumes implementation of the Gothenburg protocol and relevant EU Directives (Schöpp et al., 2003) and entails a 55, 57 and $60 \%$ reduction of $\mathrm{SO}_{4}$ deposition for 2010, 2016 and 2030 , respectively, compared to the reference year 1995/ 1996. Scale factors for the deposition in the future in relation to the reference year were calculated and the forecast was run with (calibrations $4 \mathrm{a}$ and $4 \mathrm{~b}$ ) and without (calibrations 1 and 3 ) the additional soil $\mathrm{S}$ source for Schluchsee (see above).

\section{Results}

\section{ACIDIFICATION HISTORY}

The generalised historical deposition (hindcast scenario) well matched the measured deposition data since the mid1980s for Schluchsee and Villingen catchments (Fig. 1). Over the 140-year hindcast period the $\mathrm{SO}_{4}$ fluxes in runoff increased as a result of the increasing $\mathrm{S}$ deposition.

Table 3. MAGIC input: Soil parameters for S dynamics (Langmuir isotherm parameters and additional $\mathrm{SO}_{4}$ source) for the different calibration procedures.

\begin{tabular}{lllll}
\hline Calibrations & Langmuir parameters & $\begin{array}{l}\text { half sat } \\
\text { meq } m^{-3}\end{array}$ & $\begin{array}{l}\text { max cap } \\
\text { meq } \mathrm{kg}^{-1}\end{array}$ & $\begin{array}{l}\text { add. } \mathrm{SO}_{4} \text { source } \\
\mathrm{mmol}_{c} \mathrm{~m}^{-2} \mathrm{yr}^{-1}\end{array}$ \\
\hline calibration 1 & measured* & 790 & 1.85 & none \\
calibration 2 & measured + calculated** & 790 & 0.27 & none \\
calibration 3 & result of calibration & 100 & 9.70 & none \\
calibration 4a & measured* & 790 & 1.85 & c. 60.5 \\
calibration 4b & measured* & 790 & 1.85 & const. 60.5 \\
* Kurth et al., 1989 & & & \\
** Kurth s.o., Prietzel,1998a & & &
\end{tabular}




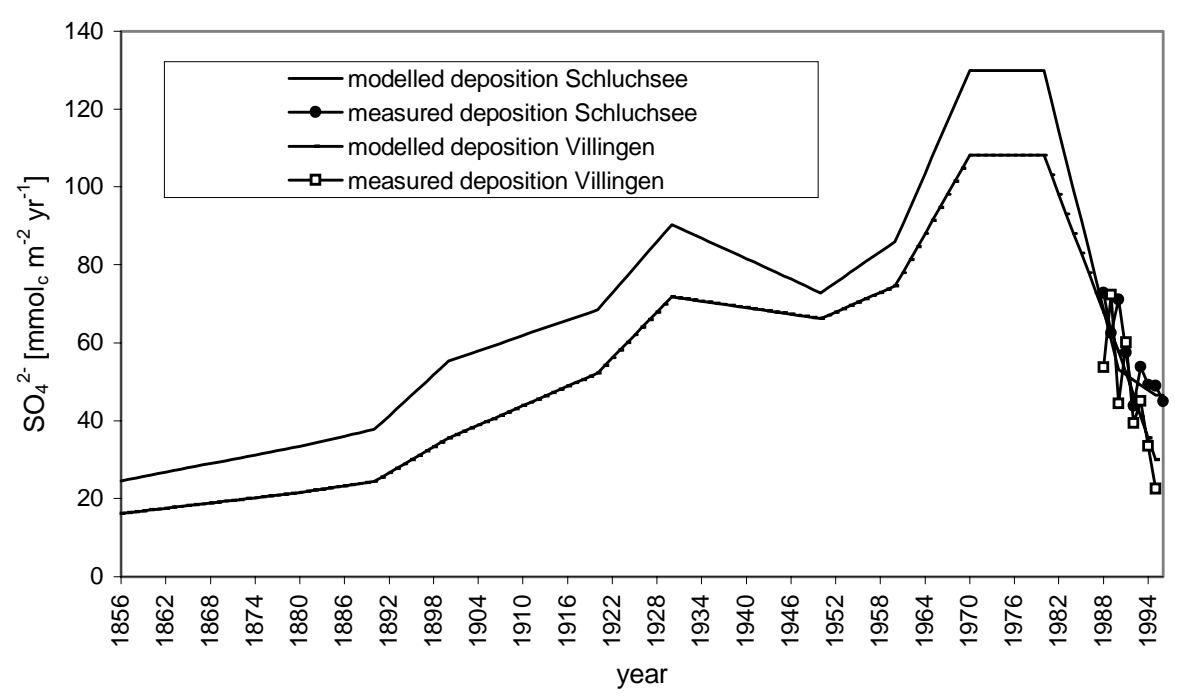

Fig. 1. Modelled and measured $\mathrm{SO}_{4}$ fluxes with input (total deposition) at Schluchsee and Villingen.

\section{MODELLING OF MEASURED STREAM SO CONCENTRATION}

Modelling $\mathrm{SO}_{4}$ concentrations in streamwater at Schluchsee using the measured LIPs (calibration 1) was not successful; the measured $\mathrm{SO}_{4}$ concentrations stream were greatly underestimated (Fig. 2). As a result, additional calibrations with various sets of input parameters for the $\mathrm{S}$ dynamics were tried. Calibration 2 was run with a smaller $\mathrm{E}_{\max }$ and the same $\mathrm{C}$ as calibration 1 (Table 3), but resulted in the same or lower $\mathrm{SO}_{4}$ concentrations in the stream (Fig. 2). Calibration 3 attempted to reach the measured $\mathrm{SO}_{4}$ concentration level by adjusting freely chosen LIPs in an interactive procedure. The best LIP was $9.7\left(\mathrm{E}_{\max }\right)$ and 100 (C), but still resulted in a $22 \%$ underestimation of $\mathrm{SO}_{4}$ concentrations. In calibration 3, MAGIC calculated a soil $\mathrm{S}_{\text {inorg }}$ pool of $1295 \mathrm{mmol} \mathrm{S} \mathrm{m}^{-2}$ in 1986, whereas the measured $\mathrm{S}_{\text {inorg }}$ pool in 1986 was only $253 \mathrm{mmol} \mathrm{S} \mathrm{m}^{-2}(0-80 \mathrm{~cm}$; Table 1b). For modelling $\mathrm{SO}_{4}$ stream concentrations with this 'ad/desorption only' approach, a more than five times larger $\mathrm{E}_{\max }$ and soil $\mathrm{S}_{\text {inorg }}$ pool compared to measured values must be assumed.

For calibration $4 \mathrm{a}$ an additional $\mathrm{S}$ source meant to comprise net mineralisation from the $\mathrm{S}_{\text {org }}$ pool was included

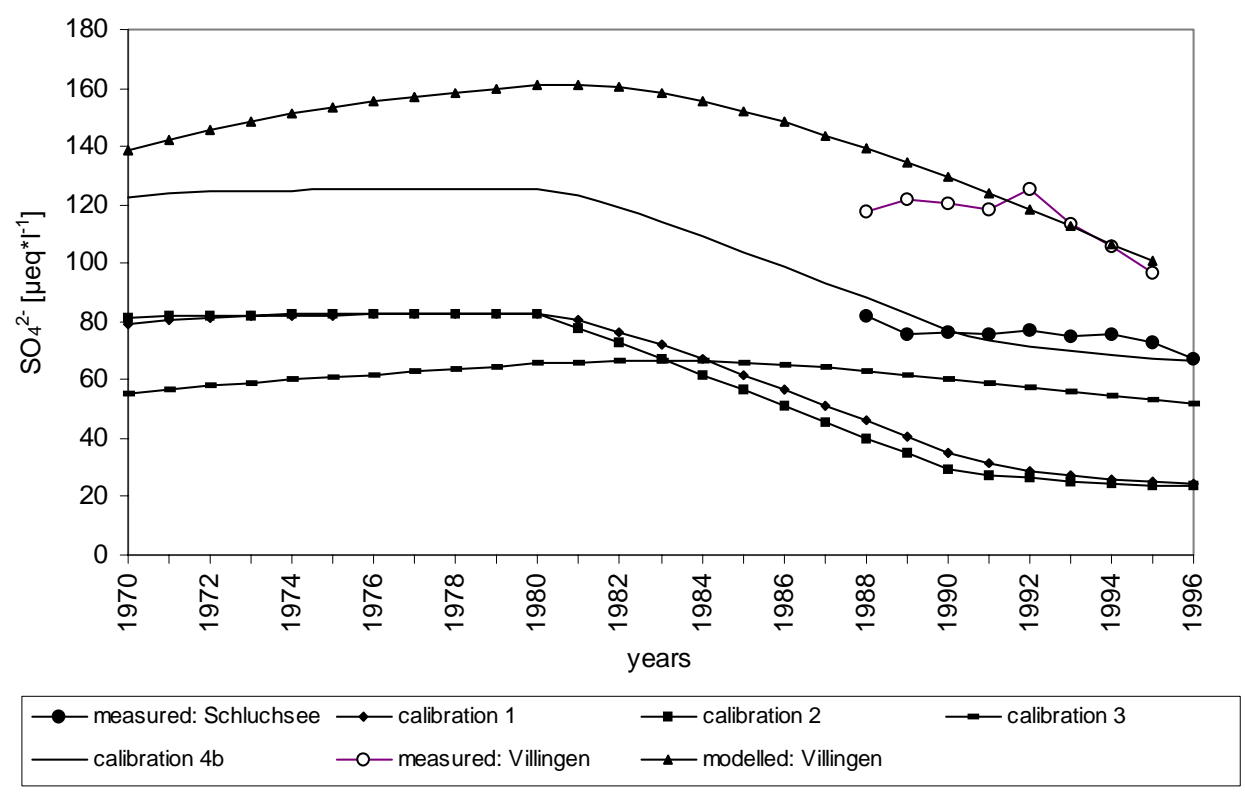

Fig. 2. Schluchsee and Villingen: Modelled compared to measured $\mathrm{SO}_{4}$ stream concentrations. 
in the same parameter file used in calibration 1 (measured LIPs). Measured data could be modelled by adding up the 'missing' $\mathrm{SO}_{4}$ with a variable $\mathrm{S}$ source which varied from year-to-year such that the modelled and measured stream $\mathrm{SO}_{4}$ concentrations matched. The average $\mathrm{S}$ source for these years $\left(60.5 \mathrm{mmol}_{\mathrm{c}} \mathrm{SO}_{4} \mathrm{~m}^{-2} \mathrm{yr}^{-1}\right)$ was then used as a constant soil $\mathrm{S}$ source in calibration $4 \mathrm{~b}$. With these additional 60.5 $\mathrm{mmol}_{\mathrm{c}} \mathrm{SO}_{4} \mathrm{~m}^{-2} \mathrm{yr}^{-1}$, measured data were matched by the model with a correlation coefficient of 0.98 .

The measured LIPs led to a successful calibration at Villingen (Fig. 2). No changes of LIPs or soil sources and sinks were necessary to achieve satisfactory simulation of $\mathrm{SO}_{4}$ concentrations in the stream. The modelled $\mathrm{SO}_{4}$ concentrations were on average 1.14 times higher than measured. The modelled soil $\mathrm{S}_{\text {inorg }}$ pool (maximum in 1980: $1145 \mathrm{mmol} \mathrm{S} \mathrm{m}^{-2}$ ) compared relatively well with the measured (Table 1b).

\section{FORECAST}

At Schluchsee stream $\mathrm{SO}_{4}$ concentrations predicted using calibration 1 decreased to $5.6 \mu \mathrm{mol}_{\mathrm{c}} \mathrm{SO}_{4} 1^{-1}$ in 2016 , a level near the modelled pre-industrial level (calibration 1, before 1856) (Fig. 3a). Calibration 3 resulted in $29.0 \mu \mathrm{mol}_{\mathrm{c}} \mathrm{SO}_{4}$ $1^{-1}$ in 2016 . With the additional $\mathrm{S}$ source, $\mathrm{SO}_{4}$ in the stream was $48.5 \mu \mathrm{mol}_{\mathrm{c}} \mathrm{SO}_{4} \mathrm{l}^{-1}$ in 2016 compared to $67 \mu \mathrm{mol}_{\mathrm{c}} \mathrm{SO}_{4}$ $\mathrm{I}^{-1}$ in 1996 (measured value). At Villingen, a $\mathrm{SO}_{4}$ stream concentration of $39.8 \mu \mathrm{mol}_{\mathrm{c}} \mathrm{SO}_{4} \mathrm{I}^{-1}$ was predicted for 2016, which is equivalent to the hindcast for 1904 (Fig. 3b).

\section{Discussion}

The modelling indicated that in these two catchments preindustrial conditions of $\mathrm{SO}_{4}$ concentrations in runoff can be reached in the next two decades, if $\mathrm{S}$ deposition declines as agreed in current legislation. The forecast concentration at Schluchsee depends highly on the magnitude of $\mathrm{S}_{\text {org }}$ released from mineralisation. The difference in the forecasts with and without an additional $\mathrm{S}$ source at Schluchsee was $43 \mu_{\mathrm{mol}} \mathrm{SO}_{4} \mathrm{l}^{-1}$ in 2016/2030 (Fig. 3a). Theoretically, and in dependency of the mineralisation dynamics, the $\mathrm{S}_{\text {org }}$ pool could, as 'worst case scenario', release the same amount of $\mathrm{SO}_{4}$ as in calibration $4 \mathrm{a} / 4 \mathrm{~b}$ constantly for decades. Without considering $\mathrm{SO}_{4}$ release from mineralisation, a faster reversibility of stream $\mathrm{SO}_{4}$ concentration was predicted at Schluchsee (Fig. 3a).

At Villingen the model suggested a relatively quick reversibility of $\mathrm{SO}_{4}$ concentrations to less than half the 1995 value in 2016 and another 50\% reduction by 2030 (Fig. $3 \mathrm{~b})$. the Uncertainty with respect to the relevant processes for $\mathrm{SO}_{4}$ release and the $\mathrm{S}_{\text {org }}$ source, however, is quite large

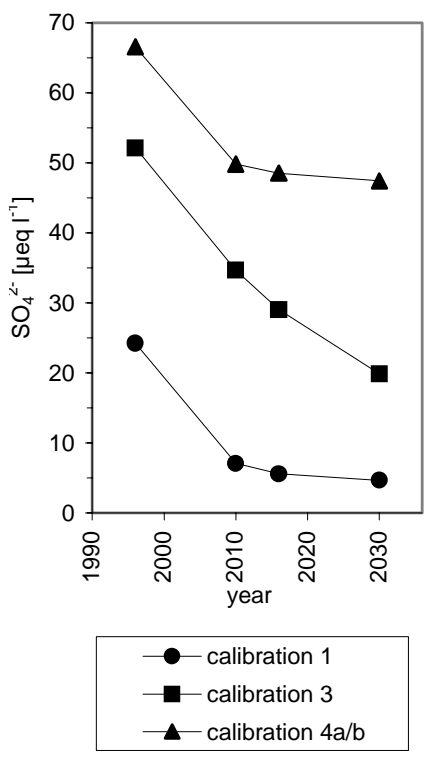

Fig. 3a. Schluchsee: Modelled $\mathrm{SO}_{4}$ stream concentration in 1996, 2010, 2016 and 2030 depending on calibration.

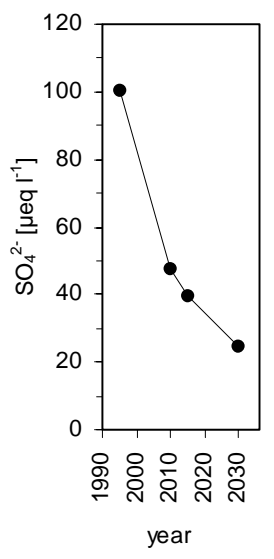

Fig. 3b. Villingen: Modelled $\mathrm{SO}_{4}$ stream concentration in 1995 , 2010, 2016 and 2030.

(Fig. 3a). Therefore, it is crucial to identify the sources of $\mathrm{SO}_{4}$ release from catchments soils for modelling future trends of stream $\mathrm{SO}_{4}$ concentrations.

In general, four major processes can be responsible for $\mathrm{S}$ release from soil: (i) desorption of inorganic $\mathrm{SO}_{4}$, (ii) oxidation of reduced $\mathrm{S}$ species, (iii) excess mineralisation of organically bound S, and (iv) weathering of S-containing minerals. Feger et al. (1990) and Mayer et al. (1995) assumed that oxidation and weathering are negligible (max. $0.013 \mathrm{mmol}_{\mathrm{c}} \mathrm{SO}_{4} \mathrm{~m}^{-2} \mathrm{yr}^{-1}$; Prietzel, 1998b) in the two catchments.

At Schluchsee, a high percentage of the annual precipitation is falls as snow. Due to this, a $10 \%$ underestimation of the $\mathrm{SO}_{4}$ input fluxes is possible (Feger 
et al., 1990). This might account for part of the 'missing' $\mathrm{SO}_{4}$ in the stream. But, increasing the amount of precipitation and the $\mathrm{SO}_{4}$ input to the catchment was not sufficient to account for the measured $\mathrm{SO}_{4}$ concentrations in the stream.

An additional soil $\mathrm{S}$ source was necessary. About 60.5


concentrations at the measured level (calibrations $4 \mathrm{a}, 4 \mathrm{~b}$ ). This amount is consistent with those reported by Feger et al. (1990), Mayer et al. (1995) and Prietzel (1998b) (62$94 \mathrm{mmol}_{\mathrm{c}} \mathrm{SO}_{4} \mathrm{~m}^{-2} \mathrm{yr}^{-1}$ ) to balance $\mathrm{S}$ flux budgets. The modelling shows that $\mathrm{SO}_{4}$ release from the catchment cannot be explained solely with ad-/desorption. Kurth et al. (1989) found that adsorption in the humus-rich podzol is largely blocked by organic anions even in the subsoil. From depleted $\delta^{18} \mathrm{O}_{\text {sulphate }}$-values in soil leachates Mayer et al. (1995) concluded that a considerable portion of $\mathrm{SO}_{4}$ in the subsoil seepage must be derived from excess mineralisation of $\mathrm{C}$ $\mathrm{S}$. On basis of $\mathrm{SO}_{4}$ fluxes and soil $\mathrm{S}$ pools (Table $1 \mathrm{~b}$ ) together with results on $\mathrm{N}$ dynamics Feger et al. (1990) and Feger (1993a) assumed that microbial turnover of relict subsoil humus pools (originating from the former deeprooting beech-fir forest stand) might be responsible for the nitrate and $\mathrm{SO}_{4}$ release at Schluchsee (Table 2c). This is supported by the fact that half of the $\mathrm{S}_{\text {org }}$ pool is stored in the B-horizon (Table 1b).

When the model was calibrated without the additional S source (calibration 3), MAGIC calculated a $\mathrm{S}_{\text {inorg }}$ pool that was five times larger than the measured $S_{\text {inorg }}$ pool in 1986. Thus, MAGIC gives an additional indication that the $\mathrm{S}_{\text {org }}$ rather than $\mathrm{S}_{\text {inorg }}$ pool is the dominant soil $\mathrm{SO}_{4}$ source at Schluchsee.

In contrast to Schluchsee, at Villingen adsorption/ desorption processes can explain the concentrations and isotope composition of $\mathrm{SO}_{4}$ in seepage water of the subsoil (Mayer et al., 1995). This is due to the high sesquioxide content in the soil (Kurth et al., 1989). This was confirmed by the successful calibration of MAGIC to the measured stream data with the measured LIPs (Fig. 2). Thus, S release from mineralisation of $\mathrm{S}_{\text {org }}$ played only a minor role, although the $\mathrm{S}_{\text {org }}$ pool still accounts for $54 \%$ of $\mathrm{S}_{\text {tot }}$ (Table 1b).

Consideration of the modelling results and $\mathrm{S}$ dynamics for these catchments leaves some questions open. This study only indicated that net mineralisation is a probable $\mathrm{SO}_{4}$ source at Schluchsee. It remains open, if the relict humus and a high microbial activity in this humus actually are the reasons for $\mathrm{SO}_{4}$ net release there as suggested by Feger et al. (1990). The question why the $\mathrm{S}_{\text {org }}$ should be mineralised in excess at Schluchsee and not at Villingen cannot be answered based on the available information. Mayer et al. (1995) concluded that at Villingen immobilization and mineralisation most likely occur concurrently at the same rate, resulting in more or less balanced $\mathrm{S}$ budgets and depleted $\delta^{18} \mathrm{O}_{\text {sulphate }}$-values in soil leachates. How the $\mathrm{S}_{\text {org }}$ pool in these catchments will react in the future, and whether it might also become a net source at Villingen remain unanswered questions. Similar uncertainties on the future behaviour of $\mathrm{S}_{\text {org }}$ were indicated for the Gårdsjön catchment in Sweden (Torssander and Mörth, 1998). There, excess mineralisation of $\mathrm{S}_{\text {org }}$ in the B-horizon (where most of it is stored) is currently not important as a $\mathrm{SO}_{4}$ source but could prolong acidification processes for centuries.

Sulphur mineralisation might increase with decreasing $\mathrm{SO}_{4}$ concentration in soil solution (Maynard et al., 1985; Simon et al., 1989). If this happens for the soil $\mathrm{S}_{\text {org }}$ pool in the studied catchments, an increasing $\mathrm{S}$ release from mineralisation in the future is likely. In addition, it is quite possible that other factors which control mineralisation (e.g. temperature, moisture) are may change in the future and could therefore influence $\mathrm{S}$ release from the $\mathrm{S}_{\text {org }}$ pool. The excess mineralisation of $\mathrm{S}_{\text {org }}$ remains a source of uncertainty for predictions of the future concentrations of $\mathrm{SO}_{4}$ in streamwater.

\section{Conclusions}

The model calibrations and S budgets from earlier studies indicated that the soil organic S pool most likely is the dominant source for $\mathrm{SO}_{4}$ release from the Schluchsee catchment. Thus, $\mathrm{S}_{\text {org }}$ and $\mathrm{S}$ mineralisation have to be considered when modelling $\mathrm{SO}_{4}$ stream concentrations there. Excess mineralisation can be modelled with MAGIC by implementing a soil $\mathrm{S}$ source. As the future dynamics of $\mathrm{S}$ release from mineralisation and the controlling factors are not clear, this process has to be taken into account as a source of uncertainty when predicting $\mathrm{SO}_{4}$ concentrations in catchments. Future research should concentrate on dynamics of S mineralisation to be able to implement a more precise description of long-term $\mathrm{S}$ mineralisation into biogeochemical models.

\section{Acknowledgements}

This project was supported financially by the Commission of European Communities RECOVER:2010 project (EVK1CT-1999-00018) and the German Ministry of Education and Research, grant no. PT BEO 51-0339476.

The assistance in modelling with MAGIC by Richard F. Wright and Jack B. Cosby is gratefully acknowledged. 


\section{References}

Alewell, C., 2001. Predicting reversibility of acidification: the European sulfur story. Water Air Soil Pollut., 130, 1271-1276.

Armbruster, M., 1998. Zeitliche Dynamik der Wasser- und Elementflüsse in Waldökosystemen. Freiburger Bodenkundl. Abh., Band 38.

Autry, A.R., Fitzgerald, J.W. and Caldwell, P.R., 1990. Sulfur fractions and retention mechanisms in forest soils. Can. J. Forest Res., 20, 337-342.

Cosby, B.J., Hornberger, G.M., Wright, R.F. and Galloway, J.N., 1986. Modeling the effects of acid deposition: control of longterm sulfate dynamics by soil sulfate adsorption. Water Resour. Res., 22, 1283-1291.

Cosby, B.J., Ferrier, R.C., Jenkins, A. and Wright, R.F., 2001. Modelling the effects of acid deposition: refinements, adjustments and inclusion of nitrogen dynamics in the MAGIC model. Hydrol. Earth Syst. Sci., 5, 499-517.

David, M.B., Mitchell, M.J. and Schindler, S.C., 1984. Dynamics of organic and inorganic sulfur constituents in hardwood forest soils. In: Forest soils and treatment impacts; Sixth North American forest soil conference, E.L. Stone, (Ed.). Knoxville, Tenn.,USA. 221-245.

Erkenberg, A., Prietzel, J. and Rehfuess, K.-E., 1996. Schwefelausstattung ausgewählter europäischer Waldböden in Abhängigkeit vom atmogenen S-Eintrag. Z. Pflanzenernaehr. Bodenkd., 159, 101-109.

European Commission, 2000. Directive 2000/60/EC of the European Parliament and of the Council of 23 October 2000 establishing a framework for Community action in the field of water policy. Official Journal L327 of 22.12.2000.

Feger, K.-H., 1993a. The ARINUS project: effects of wholewatershed nitrogen and sulfur additions on biogeochemical cycling in spruce forests. In: Ecosystems Research Report, L. Rasmussen, T. Brydges and P. Mathy (Eds.). 4, 12-22.

Feger, K.-H., 1993b. Bedeutung von ökosysteminternen Umsätzen und Nutzungseingriffen für den Stoffhaushalt von Waldlandschaften. Freiburger Bodenkundl. Abh., Band 31.

Feger, K.-H., Brahmer, G. and Zöttl, H.W., 1990. Element budgets of two contrasting catchments in the Black Forest (Federal Republic of Germany). J. Hydrol., 116, 85-99.

Fitzgerald, J.W. and Autry, A.R., 1992. Organic sulfur dynamics including mineralization and immobilization of various organic fractions. In: Atmospheric deposition and forest nutrient cycling, W.J. Dale and S.E. Lindberg (Eds.). Springer, Ecological Studies, 91, 118-129.

Gbondo-Tugbawa, S.S., Driscoll, C.T., Mitchell, M.J., Aber, J.D. and Likens, G.E., 2002. A model to simulate the response of a northern hardwood forest ecosystem to changes in $\mathrm{S}$ deposition. Ecol. Applic., 12, 8-23.

Kurth, F., Feger, K.-H. and Fischer, M., 1989. Sulfatadsorptionskapazität und Schwefelbindungsformen in Böden des Schwarzwaldes. In: Immissionsbelastung des Waldes und seiner Böden - Gefahr für die Gewässer? DVWK Mitteilungen, 17, 149-156.

Mayer, B., Feger, K.H., Giesemann, A. and Jäger, H.-J., 1995. Interpretation of sulfur cycling in two catchments in the Black Forest (Germany) using stable sulfur and oxygen isotope data. Biogeochemistry, 30, 31-58.
Maynard, D.G., Stewart, J.W.B. and Bettany, J.R., 1985. The effects of plants on soil sulfur transformations. Soil Biol. Biochem., $17,127-134$.

McGill, W.B. and Cole, C.V., 1981. Comparative aspects of cycling of organic C, N, S and P through soil organic matter. Geoderma, 26, 267-286.

Mitchell, M.J., David, M.B., Maynard, D.G. and Telang, S.A., 1986. Sulfur constituents in soils and streams of a watershed in the Rocky Mountains of Alberta. Can. J. Forest Res., 16, 315320.

Mylona, S., 1996. Sulphur dioxide emissions in Europe 18801991 and their effect on sulphur concentrations and depositions. Tellus, 48B, 662-689.

Norman, A.L., Giesemann, A., Krouse, H.R. and Jäger, H.J., 2002. Sulphur isotope fractionation during sulphur mineralization: results of an incubation-extraction experiment with a Black Forest soil. Soil Biol. Biochem., 34, 1425-1438.

Prechtel, A., Alewell, C., Armbruster, M., Bittersohl, J., Cullen, J.M., Evans, C.D., Helliwell, R., Kopácek, J., Marchetto, A., Matzner, E., Meesenburg, H., Moldan, F., Moritz, K., Vesely, J. and Wright, R., 2001. Response of sulphur dynamics in European catchments to decreasing sulphate deposition. Hydrol. Earth Syst. Sci., 5, 311-325.

Prietzel, J., 1998a. Untersuchungen zur Boden-SchwefelAusstattung zweier Schwarzwaldstandorte - räumliche Variabilität, zeitliche Dynamik und Auswirkungen experimenteller Sulfatgaben. Habilitation Thesis, University of Munich, 1-399.

Prietzel, J., 1998b. Untersuchungen zum S-Haushalt Zusammenfassende Diskussion. In: Ökosystemforschung im Schwarzwald, S. Raspe, K.H. Feger and H.W. Zöttl (Eds.). Ecomed, Freiburg, Germany. 1-533.

Prietzel, J., Weick, C., Korintenberg, J., Seybold, G., Thumerer, T. and Treml, B., 2001. Effects of repeated $\left(\mathrm{NH}_{4}\right)_{2} \mathrm{SO}_{4}$ application on sulfur pools in soil, soil microbial biomass, and ground vegetation of two watersheds in the Black Forest/ Germany. Plant Soil, 230, 287-305.

Reuss, J.O. and Johnson, D.W., 1985. Effect of soil processes on the acidification of water by acid deposition. J. Environ. Qual., 14, 26-31.

Schöpp, W., Posch, M., Mylona, S. and Johansson, J., 2003. Trends in acid deposition (1880-2030) for sensitive freshwater regions in Europe. Hydrol. Earth Syst. Sci., 7, 436-446.

Simon, B., Feger, K.-H. and Zöttl, H.W., 1989. Mikrobielle Nund S-Umsetzungen im Auflagehumus und oberen Mineralbodenhorizonten von Schwarzwaldböden. In: Immissionsbelastung des Waldes und seiner Böden - Gefahr für die Gewässer? DVWK Mitteilungen, 17, 157-165.

Sullivan, T.J. and Cosby, B.J., 1998. Modeling the concentration of aluminium in surface waters. Water Air Soil Pollut., 105, 643-659.

Torssander, P. and Mörth, C.-M., 1998. Sulfur dynamics in the roof experiment at Lake Gårdsjön deduced from sulfur and oxygen isotope ratios in sulfate. In: Experimental reversal of acid rain effects: The Gårdsjön roof project, $\mathrm{H}$. Hultberg and R. Skeffington (Eds.). Wiley, Chichester, UK, 185-206. 